Riding the Tiger 


\section{By the same author}

Developmental States in East Asia (editor)

The Chinese State in the Era of Economic Reform:

The Road to Crisis (editor) 


\title{
Riding the Tiger
}

The Politics of Economic Reform in Post-Mao China

\author{
Gordon White \\ Professorial Fellow \\ Institute of Development Studies \\ at the University of Sussex
}

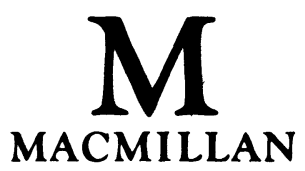


All rights reserved. No reproduction, copy or transmission of this publication may be made without written permission.

No paragraph of this publication may be reproduced, copied or transmitted save with written permission or in accordance with the provisions of the Copyright, Designs and Patents Act 1988, or under the terms of any licence permitting limited copying issued by the Copyright Licensing Agency, 90 Tottenham Court Road, London W1P 9HE.

Any person who does any unauthorised act in relation to this publication may be liable to criminal prosecution and civil claims for damages.

First published 1993 by

THE MACMILLAN PRESS LTD

Houndmills, Basingstoke, Hampshire RG21 2XS

and London

Companies and representatives

throughout the world

ISBN 978-0-333-45481-7

ISBN 978-1-349-22651-1 (eBook)

DOI 10.1007/978-1-349-22651-1

A catalogue record for this book is available from the British Library.

Copy-edited and typeset by Povey-Edmondson

Okehampton and Rochdale, England 
騎虎难下

qi hu nan xia

'If you're riding a tiger, it's

hard to get off.'

(Chinese saying) 


\section{Contents}

List of Tables $\quad \mathrm{x}$

List of Figures

Abbreviations xii

Acknowledgements xiii

Introduction 1

The comparative context of post-Mao reforms 4

General theses and focus 11

A framework for analysing the politics of economic reform 13

1 The Failure of the Maoist Developmental State and the Rise of the Economic Reformers 21

Maoism and the socialist development state 21

The demise of Maoism and the rise of the reformers 25

The political origins of Chinese economic reform 29

The economic reform paradigm $\quad 42$

2 The Political Dynamics of Chinese Economic Reform:

An Overview

An overview of reform from 1979 on 51

The effects of reform on the relations between state and economy $\quad 71$

The political dynamics of economic reform $\quad 77$

3 The Politics of Agrarian Reform 85

A framework for analysing the politics of agricultural policy

The political background of rural reform: the commune system

The politics of decollectivisation 
Conclusion: changes in the politics of Chinese agriculture

4 The Politics of Industrial Reform

A framework for analysing the politics of industrial reform

The background to industrial reform

The reforms in industrial strategy and structure

Reforming industrial administration: relations between state and enterprises

Conclusion: the political deadlock in industrial reform

5 Economic Reform and Ideological Decay: The Decline of Ideocracy

Ideological demolition and the legacy of Mao

Ideological reconstruction and adaptation

Ideology in decay

6 The Party's Over? Economic Reform and

Institutional Decay

Efforts at institutional rehabilitation

Efforts at institutional reform

Conclusion: the struggle between the two parties

7 The Social Impact of Economic Reform: The Rise of Civil Society?

Chinese social structure and organisation in the pre-reform era

The impact of economic reform on Chinese society

Economic reforms and the rise of 'civil society'

Conclusion: towards a civil society?

8 From Market Socialism to Social Market?

The political impact of economic reform: what has changed?

The nature and feasibility of political reform:

whither next? 


\section{Contents ix}

The nature of the political transition to democracy 247

Concluding remarks 255

Notes 258

Bibliography 271

$\begin{array}{ll}\text { Index } & 280\end{array}$ 


\section{List of Tables}

I.1 Top Party and State Leaders, 1976-91 15

I.2 Chinese Communist Party Central Committee:

Politburo Standing Committees

1.1 Agricultural Growth 1952-91: Indices of Growth in Gross Output Value

1.2 Industrial Growth 1950-91: Indices of Growth in Gross Output Value

1.3 Indices of Per Capita Consumption, 1953-90 34

2.1 China's Foreign Trade, 1978-91 73

6.1 Educational Level of Party Members 189

7.1 The Composition of the (Annual) Average Per

Capital Net Incomes of Rural Households According to Group of Households

7.2 Average Annual Income of Residents and Workers 205

7.3 Price Indices 1978-91 206 


\section{List of Figures}

I.1 The Party/State Centre (Simplified)

18

I.2 The Structure of China's Governmental System

3.1 State Level Organisational Arrangements for the Administration of Rural Policy 


\section{Abbreviations}

FBIS Foreign Breadcast Information Service, China: Daily Report.

GMRB Guangming Ribao (Glorious Daily), Beijing.

NCNA New China News Agency (Xinhua), Beijing.

RMRB Renmin Ribao (People's Daily), Beijing.

$S S B \quad$ State Statistical Bureau, Statistical Yearbook, Beijing.

$S W B \quad$ British Broadcasting Corporation, Summary of World Broadcasts: Far East.

ZGSHTJZL Zhongguo Shehui Tongji Ziliao 1990 (Statistical Materials on Chinese Society) Beijing, Chinese Statistics Publishing House, 1990. 


\section{Acknowledgements}

The author would like to thank the following for their valuable advice and assistance in completing this work: Bob Benewick, Marc Blecher, Robert and Shu Cassen, Jack and Maisie Gray, Barbara Harriss-White, Jude Howell, Julie McWilliam, Peter Nolan, Akio Takahara and Adrian Wood.

I would also like to express my gratitude to numerous Chinese colleagues and friends with whom I have discussed the content of this work, with particular thanks to Shang Xiaoyuan, Yang $\mathrm{Mu}$ and Duan Shunchen.

A special debt of gratitude is due to my publisher, Steven Kennedy, who has been patient and supportive throughout.

GoRDON WHITE 